\title{
CORRIGENDUM
}

\section{AN UNKNOWN PREFACE FROM DIODORUS' BIBLIOTHÊKÊ (BOOK 34)? - CORRIGENDUM}

\section{PIOTR WOZNICZKA}

doi:10.1017/S0009838821000914, Published by Cambridge University Press, 13 October 2021.

The article title and running heads have been updated to correct a spelling error since the original publication.

The publisher apologises for the error.

Reference

Wozniczka, P. (2021). AN UNKNOWN PREFACE FROM DIODORUS' BIBLIOTHÊKÊ (BOOK 34)? The Classical Quarterly, 71(2), 655-675. doi:10.1017/S0009838821000914. 